\title{
安全性の向上，環境負荷低減を目指した農薬製剂・施用技術 ${ }^{*}$ 一最近の動向一
}

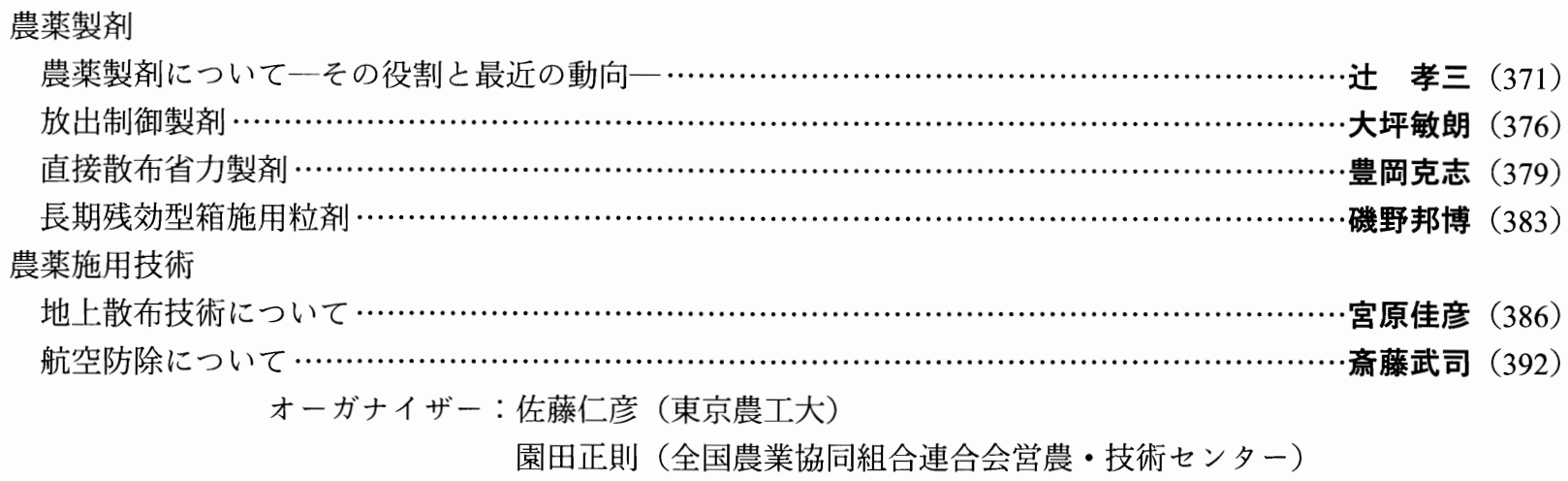

農薬に之って安全性の向上，環境への負荷低減は大きな テーマであり, 各分野で広く研究が進んでいる。同様に, 農作業者に直接係る農薬製剂あるいは農薬施用技術の進歩 あ著しいものがある. 1947 年に農薬製剤が本格的に工業 化されて以来, 各種の農薬剤型が開発されてきた。近年に なって, 時代の要請に沿うかたちで安全性向上, 環境負荷 低減および省力化を目的に非常な勢いで各種製剤技術が開 発されている. また, 農薬施用技術も航空, 地上散布を含 めて大きな発展を遂げてきた。

農薬製剂・施用法研究会は 1981 年に第一回を開催して 以来, 今年で 23 回目を迎える. 本研究会む年々盛会とな りこの数年では約 250 名という多くの参加者に至っている. 内容は農薬製剤技術や農薬施用技術を始めとして多岐に亘っ ての講演や技術研究発表がなされているが, 近年は安全性, 環境あるいは省力化に関係する発表が多い.

今回は農薬学会第 28 回大会のシンポジゥムとして「安 全性の向上，環境負荷低減を目指した農薬製剤・施用技術一 最近の動向一」をテーマとして取り上げ日本農薬学会と共 催した。講演者には農薬製剂扔よび施用法の部門で活躍さ れている研究者の方々にお願いし講演をして頂いた. 内容 を農薬製剂之農薬施用技術の 2 部に別け，それぞれ 4 件と 2 件の合計 6 件で構成した. いずれも現状から将来への展 望を含めた講演をして頂き, 有意義なシンポジゥムであっ た。

\footnotetext{
\#第 28 回大会シンポジウムをとりまとめた解説.

* 干243-0023 神奈川県厚木市戸田 2165 北興化学工業 (株) 開発研究所
}

辻 孝三氏：農薬製剂の目的抢よび重要性から始まり， 現行製剤の問題点之対策抢よび今後の展望についての広範 囲な話しであった，特に，環境への負荷低減之いう観点か ら農薬送達システム（Pesticide Delivery System：PDS）が これからの重要な技術になると指摘された。

大坪敏朗氏 : 残効性の付与, 薬害の軽減など種々の機能 を持たせる製剂技術として放出制御技術は有効な手段であ る. 現状での放出制御技術の紹介と特に演者が携わったマ イクロカプセル製剤技術の放出理論について分かり易く説 明された。 今後, 進展することが予想される重要な製剤技 術と考えられる.

豊岡克志氏：環境負荷低減や省力化を目的とした直接散 布製剤は近年急速に增加している. SC 剂, EW 剂などの 液状製剤や粒剂 (U 粒剂)，ジャンボ剤などの固形製剤の 特徴と今後の展望について詳細に話しをして頂いた。 今後 は製剤技術と施用技術がジョイントして，より環境負荷低 減を図った省力製剤の開発が進むことを予想された。

磯野邦博氏：近年になって急速に普及してきた製剤に長 期残効型箱施用粒剂がある. 環境負荷低減や省力化の観点 から見ると非常に優れた製剤といえる. 演者は本箱粒剤の 特徴およびその製剂技術を詳細に説明された. 今後, 更に 機能性の高い製剂が開発されることと考えられる.

宮原佳彦氏：環境への負荷低減や作業者への安全性確保 には散布機や散布方法が大きく関与する。我が国における 地上散布技術の現状々問題点を上げ，それに対する散布機 の開発動向を水稲, 畑, 果樹, 施設園芸用に別けて詳細に 説明された。 
斎藤武司氏：航空防除は省力技術であることはもちろん， 効率的で経済的な技術であるため広く普及している。しか し，ドリフトによる周辺環境に及ぼす影響が懸念されてい ることから大気中の農薬濃度や大気中での挙動について調 査した結果を報告された。併せてドリフトの更なる低減化
技術について講演された。

近年，農薬製剂抢よび農薬施用技術の進歩，発展は目覚 しいものがあるが，今後更に製剤之施用技術が相俟って農 薬の安全性向上および環境負荷低減に貢献していくものと 思われる。

（*米村伸二記） 